\title{
PENINGKATAN HASIL BELAJAR MATEMATIKA SISWA KELAS IV SDN 008 LANGGINI MELALUI PENERAPAN PEMBELAJARAN KOOPERATIF DENGAN TEKNIK KANCING GEMERINCING
}

\author{
Rusdial Marta \\ Surel : dial.fredo90@gmail.com
}

\begin{abstract}
ABSTRAK
Keberhasilan guru mengajar harus memperhatikan metode pembelajaran. Model pembelajaran yang mengaktifkan siswa adalah pembelajaran kooperatif dengan teknik kancing gemerincing. Tujuan penelitan untuk mendeskripsikan penerapan pembelajaran ini dapat meningkatkan hasil belajar matematika. Jenis penelitian yaitu tindakan kelas. Subjeknya siswa kelas IV SDN 008 Langgini, dengan jumlah 23 orang. Data hasil penelitian ini hasil tes dan lembar observasi. Hasil analisis diperoleh persentase siswa tuntas belajar siklus I 78,13\% dan siklus II 90,63\%. Nilai rata-rata siklus I 74,54 dan siklus II 81,88 . Persentase rata-rata pelaksanaan pembelajaran matematika siklus I $81,25 \%$ dan siklus II 93,30\%. Hasil diperoleh pembelajaran matematika dapat menigkatkan hasil belajar matematika.
\end{abstract}

Kata Kunci : Hasil Belajar, Model Pembelajaran Kooperatif, Pembelajaran Matematika

\section{PENDAHULUAN}

Untuk meningkatkan hasil belajar matematika siswa, maka seorang guru dituntut untuk menggunakan strategi yang dapat melibatkan siswa aktif. Dengan demikian untuk menciptakan suasana yang menyenangkan dan untuk meningkatkan hasil belajar maka seorang guru dituntut untuk memilih metode yang tepat dan efektif dalam proses pembelajaran. Slameto (1995:64) mengatakan bahwa "salah satu faktor yang mempengaruhi belajar adalah metode mengajar".

Jadi guru harus mampu menentukan metode mengajar serta alat bantu yang tepat sehingga bahan yang di sajikan sesuai dengan tujuan yang hendak di capai dan mudah di terima siswa. Berdasarkan hasil observasi yang penulis lakukan di kelas IV SDN 008 Langgini Tahun Ajaran 2016/2017 bahwa kenyataannya metode mengajar yang sering digunakan guru adalah metode ceramah, tanya jawab dan pemberian tugas, yang mana metode ini masih kurang dapat meningkatkan hasil belajar siswa. Ini terlihat dari rata-rata matematika siswa kelas IV SDN 008 Langgini semester ganjil masih kurang dari Kriteria Ketuntasan Minimal yaitu 65. Dari 23 siswa hanya 9 orang yang mencapai KKM 65. Jika dipersentasekan hasil belajar matematika siswa hanya mencapai $39 \%$. Usaha lain yang telah dilakukan 
guru untuk mengatasi permasalahan di atas yaitu dengan pembelajaran kelompok, tapi hanya sebagian kecil anggota kelompok yang aktif belajar mengerjakan latihan yang diberikan. Hal ini dapat dilihat dari siswa yang aktif dalam diskusi siswa yang pintar saja, sementara siswa yang mempunyai kemampuan rendah hanya diam dan tidak ikut diskusi, sehingga peningkatan hasil belajarnya kurang tampak. Dari hasil wawancara penulis dengan guru matematika kelas IV SDN 008 Langgini bahwa siswa yang diajarkan dengan pembelajaran kelompok mereka lebih banyak bermain, bercerita dan menunggu hasil dari temannya saja, hanya sebagian kelompok kecil yang mengerjakan tugas yang diberikan, sehingga banyak siswa yang tidak mengerti dengan hasil diskusi kelompok. Ini mengakibatkan motivasi dan hasil belajar siswa tersebut banyak yang rendah.

Berdasarkan observasi dan wawancara yang penulis lakukan, maka dapat disimpulkan bahwa dengan belajar kelompok peningkatan hasil belajar siswa belum terjamin kalau semua anggota kelompok tidak aktif. Untuk mengatasi masalah di atas, guru sebagai salah satu komponen utama dalam proses pembelajaran diharapkan mampu menciptakan kondisi sedemikian rupa sehingga dapat merangsang siswa untuk belajar aktif. Guru harus memilih dan menggunakan strategi dan pendekatan, metode dan teknik yang banyak menyebabkan siswa aktif dalam belajar sehingga pembelajaran dapat berlangsung dengan baik. Salah satu upaya yang memungkinkan itu terjadi adalah dengan penerapan model pembelajaran kooperatif. Untuk itu pembelajaran kooperatif mempunyai potensi yang besar untuk membuat semua saling berinteraksi, karena dalam pembelajaran kooperatif telah dirancang pembelajaran sedemikian rupa sehingga siswa yang satu dapat berinteraksi dengan siswa yang lainnya. Pelaksanaan pembelajaran kooperatif dapat dilakukan dengan bermacam-macam teknik yaitu : bertukar pasangan, berpikir berpasangan, berkirim salam dan soal, kepala bernomor, kepala bernomor terstruktur, dua tinggal dua tamu, kancing gemerincing, keliling kelas dan lain-lain dalam Lie (2002 : 21). Salah satu dari teknik pembelajaran kooperatif di atas yang diperkirakan dapat mengatasi peran yang dominan dalam kelompok adalah kancing gemerincing. Masing-masing siswa diberikan kancing dengan jumlah tertentu. Ketika siswa menjawab dan mengeluarkan pendapat, maka siswa menyerahkan salah satu kancingnya ke tengah kelompok. Jika kancingnya telah habis, maka siswa tidak boleh memulai berbicara sampai semua rekannya juga menghabiskan kancing mereka. Jadi kancing gemerincing dalam proses pembelajarannya selain siswa berdiskusi sesamanya siswa juga mempunyai kesempatan yang 
sama untuk berpartisipasi dalam kelompoknya. Sehingga terjadi pemerataan kesempatan dalam kelompok.

Berdasarkan uraian di atas maka dapat dirumuskan masalah sebagai berikut: Bagaimanakah Peningkatan Hasil Belajar Matematika Siswa Melalui Penerapan Pembelajaran Kooperatif dengan Teknik Kancing Gemerincing di Kelas IV SDN 008 Langgini?

Penelitian ini bertujuan untuk meningkatkan hasil belajar Matematika pada materi operasi perkalian dan pembagian siswa kelas IV Sekolah Dasar Negeri 008 Langgini dengan penerapan pembelajaran kooperatif dengan teknik kancing gemerincing.

\section{METODE PENELITIAN}

Sesuai dengan permasalahan yang telah dikemukakan di atas, maka jenis penelitian ini adalah penelitian tindakan kelas (PTK). Wardani, dkk (2004:14) mengemukakan bahwa : Penelitian tindakan kelas adalah penelitian yang dilakukan oleh guru di dalam kelasnya sendiri melalui refleksi diri, dengan tujuan untuk memperbaiki kinerjanya sebagai guru, sehingga hasil belajar siswa makin meningkat. Dalam pelaksanaan penelitian dilakukan dalam beberapa siklus yang tiap siklus terdiri dari empat tahap yaitu :

\section{Tahap Perencanaan}

Pada tahap ini peneliti bersama guru bidang studi merencanakan kegiatan dan menetapkan waktu dan cara penyajian, menyiapkan rencana pembelajaran (RP), alat observasi, menentukan alteranative tindakan yang dapat dilakukan, menyiapkan alat dan teknis analisis data.

\section{Tahap Pelaksanaan}

Pelaksanaan merupakan tahap lanjutan dari perencanaan, pada tahap ini peneliti melaksanakan tindakan yang telah disepakati bersama pada tahap perencanaan.

\section{Pengamatan}

Pada tahap ini peneliti sebagai observer mengobservasi tindakan yang sedang dilakukan oleh guru.

\section{Refleksi}

Refleksi merupakan tahap akhir dari suatu daur penelitian tindakan kelas pada tahap ini observer dan guru mendiskusikan hasil tindakan berupa lembar observasi, tes dan masalah yang terjadi di kelas IV SDN 008 Langgini di kelas penelitian. Dengan demikian refleksi dapat ditentukan setelah adanya tindakan yang didapat melalui analisa lembar observasi dan tes. Setelah melakukan refleksi biasanya muncul permasalahan atau pikiran baru, sehingga merasa perlu perencanaan ulang, tindakan ulang, dan refleksi ulang.

$\begin{array}{lr}\text { Demikian tahapan } & \begin{array}{l}\text { kegiatan } \\ \text { sehingga }\end{array} \\ \text { terus berulang-ulang } & \\ \text { membentuk siklus yang kedua, siklus }\end{array}$


yang ketiga, dan seterusnya sampai suatu permasalahan dianggap teratasi.

Penelitian ini dilakukan dalam dua siklus, satu siklus terdiri dari 2 pertemuan, daur siklus penelitian tindakan kelas (PTK) menurut Arikunto (2006:16) adalah sebagai berikut :

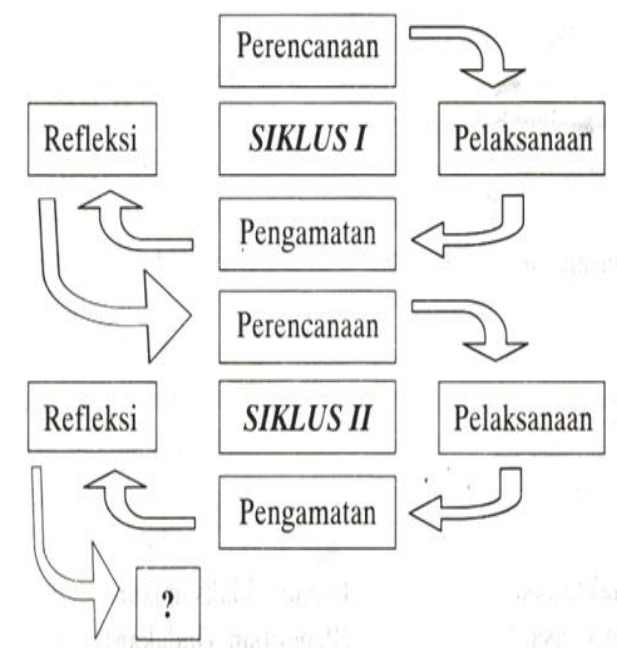

Penelitian ini mengambil lokasi di Sekolah Dasar Negeri 008 Langgini. Sesuai dengan standar kompetensi (SK) dan kompetensi dasar (KD) yang telah ditetapkan oleh pusat, maka penelitian ini akan dilaksanakanpada semester ganjil tahun ajaran 2016/2017. Objek dalam penelitian ini adalah seluruh siswa kelas IV Sekolah Dasar Negeri 008 Langini yang berjumlah 23 orang siswa terdiri dari 7 orang siswa lakilaki dan 16 orang siswa perempuan.

\section{HASIL DAN PEMBAHASAN}

1. Siklus I

a. Perencanaan Tindakan

Perencanaan dilakukan setelah mengetahui suatu permasalahan. permasalahan pada siklus I ini yaitu kurang aktifnya setiap anggota kelompok dalam memberikan tanggapan, jawaban, dan sanggahan dalam berdiskusi menjawab latihan yang diberikan guru sehingga koordinasi dan kerjasama antar kelompok tidak terjalin dengan baik ini disebabkan karena siswa yang aktif dalam diskusi siswa yang pintar saja, sementara siswa yang mempunyai kemampuan rendahhanya diam dan tidak ikut diskusi. Permasalahan tersebut untuk mengidentifikasi awal terhadap tindak yang akan dilakukan. Pada tahap ini kegiatan yang dilakukan adalah merencanakan tindakan yang terdiri dari membuat Rencana Pelaksanaan Pembelajaran (RPP), menyiapkan lembaran observasi dan menyiapkan alat bantu berupa kancing baju dan mendiskusikan langkah-langkah pembelajaran dengan mengunakan penerapan pembelajaran kooperatif dengan teknik kancing gemerincing dengan guru kelas IV SDN 008 Langgini. Materi yang diberikan adalah operasi perkalian dan pembagian.

b. Pelaksanaan Tindakan

Pada pertemuan pertama kegiatan yang dilakukan guru adalah membuka pelajaran lalu guru memperkenalkan metode pembelajaran kooperatif dengan teknik kancing gemerincing dimana mereka dibagi atas kelompok kelompok kecil yang terdiri dari 5-6 orang siswa berdasarkan kemampuan akademik, kemudian siswa diminta 
duduk berdasarkan kelompoknya, selanjutnya guru menekankan kepada siswa bahwa untuk pertemuan berikutnya mereka diharapkan sudah duduk menurut kelompoknya masingmasing. Kegiatan inti pembelajaran dimulai guru dengan mengikuti prosedur pembelajaran yang ada pada RPP. Guru menjelaskan materi secara garis besar ditambah satu contoh yang ada dalam buku. Untuk selanjutnya siswa diminta memperdalam materi yang terdapat dalam buku dan apabila mengalami kesulitan boleh bertanya kepada teman sekelompoknya.

Selesai memperdalam materi siswa disuruh mengerjakan soal-soal yang ada dalam buku terdiri dari 8 soal, yang penyelesaianya mengunakan pembelajaran kooperatif dengan teknik kancing gemerincing. Disini guru membimbing dan mengarahkan siswa agar benar-benar memahami soal yang dikerjakan yang tujuanya untuk persiapan kuis diakhir jam pelajaran. Setelah selesai guru memberikan klarifikasi dan penekanan konsep. Diakhir pelajaran guru bersama siswa menyimpulkan pelajaran yang mereka pelajari hari ini, selama 10 menit diberikan kuis sebanyak dua soal yang tujuannya untuk menentukan penghargaan kelompok dan memberikan PR.

Pada pertemuan pertama ini kegiatan kelompok tidak berjalan dengan baik ini disebabkan karna banyak siswa yang ribut, keributan ini karena ada beberapa siswa yang ingin ditukar sesuai kelompok yang mereka inginkan tapi guru memberikan pengertian kepada setiap anggota kelompok sehingga akhirnya mereka berkelompok sesuai dengan yang telah ditetapkan.

Pada pertemuan kedua kegiatan yang dilakukan guru adalah membuka pelajaran, membagikan kuis pada pertemuan pertama yang dilanjutkan dengan memberikan penghargaan kepada kelompok yang memiliki nilai tertinggi dan meminta siswa mengumpulkan PR pada pertemuan pertama. Kemudian guru membahas soal-soal yang dianggap sulit oleh siswa dengan jalan menunjuk salah satu siswa untuk mengerjakan kedepan.

Kegiatan inti pembelajaran dimulai guru dengan mengikuti prosedur pembelajaran yang ada pada RPP. Guru menjelaskan materi secara garis besar ditambah satu contoh yang ada dalam buku. Untuk selanjutnya siswa diminta memperdalam materi yang terdapat dalam buku dan apabila mengalami kesulitan boleh bertanya kepada teman sekelompoknya. Selesai memperdalam materi siswa disuruh mengerjakan soal-soal yang ada dalam buku terdiri dari 5 soal, yang penyelesaianya mengunakan pembelajaran kooperatif dengan teknik kancing gemerincing. Disini guru membimbing dan mengarahkan siswa agar benar-benar memahami soal yang dikerjakan yang tujuanya untuk persiapan kuis diakhir jam pelajaran. Setelah selesai guru memberikan klarifikasi dan 
penekanan konsep. Diakhir pelajaran guru bersama siswa menyimpulkan pelajaran yang mereka pelajari hari ini, selama 10 menit diberikan kuis sebanyak dua soal yang tujuannya untuk menentukan penghargaan kelompok dan memberikan PR. Pada pertemuan kedua ini kegiatan kelompok tidak berjalan dengan baik ini disebabkan karena metode yang di laksanakan masih baru menurut siswa, sehingga siswa sulit untuk menyesuaikanya dengan pembelajaran sebelumnya.

\section{c. Observasi}

Observasi dilakukan terhadap pelaksanaan pembelajaran setiap pertemuan. Catatan observer pada lembar observasi siklus I akan dijadikan refleksi untuk siklus II. Dari hasil analisis diperoleh penilaian pelaksanan pembelajaran dengan menggunakan penerapan pembelajaran kooperatif dengan teknik kancing gemerincing sudah baik. Ini terlihat dari persentase yang diperoleh yaitu $81,25 \%$.

Dari hasil observasi ini setiap aspek yang dinilai, mulai dari yang pertama pendahuluan yang terdiri pembukaan sudah baik, memotivasi siswa cukup baik dan memberikan indikator pencapaian hasil dilihat juga cukup baik, yang kedua kegiatan inti yang terdiri dari menjelaskan materi secara garis besar sudah baik, kegiatan kelompok dalam pembelajaran kooperatif dengan teknik kancing gemerincing kurang baik, evaluasi sudah baik dan cara guru memberikan pengguatan pada umumnya cukup baik dan yang ketiga adalah penutup yang terdiri dari guru mengarakan siswa membuat rangkuman cukup baik dan guru memberikan PR sudah sudah baik.

\section{d. Refleksi}

Dari tindakan dan observasi siklus I diperoleh data. Data diolah dan dianalisis yaitu dari hasil analisis lembar observasi diperoleh penilaian pelaksanaan pembelajaran dengan menggunakan penerapan pembelajaran kooperatif dengan teknik kancing gemerincing sudah cukup baik ini terlihat dari persentase yang diperoleh yaitu $81,25 \%$.

Berdasarkan hasil observasi tersebut maka peneliti mengidentifikasi masalah-masalah yang terjadi pada pembelajaran siklus I yaitu siswa masih sulit menerima metode yang diberikan karena pada pembelajaran sebelumnya siswa hanya menerima materi yang diberikan guru, guru kesulitan dalam mengelola waktu karena dalam memberikan penghargaan kelompok diawal pelajaran membuat siswa ribut dan menyita waktu yang cukup banyak, siswa masih menuntut peranan aktif guru dalam membimbing dan memotivasi siswa dikarnakan metode yang diterapkan masih baru menurut siswa. Refleksi hasil tes dari data hasil tes siklus I secara klasikal rata-rata hasil tes 74,54. Persentase jumlah siswa yang tuntas belajar $78,13 \%$. 
Hal ini menunjukan belum tercapainya hasil belajar secara klasikal. Berdasarkan perolehan data di atas, guru menyimpulkan belum tercapainya hasil belajar tersebut dipengaruhi banyak faktor, faktor yang mempengaruhinya berasal dari guru dan dari siswa. Faktor tersebut antara lain bagi guru bidang studi yaitu kurang aktifnya guru dalam membimbing siswa pada penerapan pembelajaran kooperatif dengan teknik kancing gemerincing. Ini disebabkan karna guru sibuk memeriksa PR pada pertemuan sebelumnya. Guru mempunyai kemampuan yang terbatas dan belum punya banyak pengalaman mengajar sehingga pengelolaan kelas dinilai masih kurang, yang membuat siswa masih banyak ribut dalam belajar. Bagi siswa pembelajaran kooperatif dengan teknik kancing gemerincing merupakan hal yang baru, sehingga dalam pelaksanaannya siswa mengalami banyak perubahan cara belajar.

\section{Siklus II}

\section{a. Perencanaan Tindakan}

Pada tahap perencanaan guru melaksanakan pembelajaran siklus II yang bertitik tolak dari hasil refleksi pada siklus I. Dari hasil analisis dan refleksi siklus I dapat disimpulkan bahwa dalam penerapan pembelajaran kooperatif dengan teknik kancing gemerincing, guru masih kesulitan dalam mengelola waktu, penguasaan kelas, siswa masih menuntut peran aktif guru dalam membimbing dan memotivasi siswa, sedangkan hasil belajar matematika siswa masih rendah ini disebabkan karena belum tercapainya hasil belajar secara klasikal.

Pada tahap perencanaan ini peneliti dan guru kelas IV SDN 008 Langgini, mengidentifikasi permasalahan yang didapat pada siklus I yaitu pada penerapan pembelajaran kooperatif dengan teknik kancing gemerincing, siswa diminta berurutan menurut arah jarum jam dalam menjawab latihan yang diberikan guru pada lembaran jawaban kelompok dan dalam memberikan penghargaan kelompok guru memberikanya diakhir pelajaran, hal ini dilakukan agar tidak terjadi keributan dalam menjawab dan tidak mengurangi waktu pengerjaan soal berikutnya. Kemudian guru dalam membahas PR pada pertemuan sebelumnya, hendaknya dilakukan diluar jam pembelajaran. Ini dimaksudkan agar guru lebih membimbing dan memperhatikan siswa dalam menyelesaikan soal yang diberikan. Merencanakan tindakan, yang terdiri dari membuat rencana pembelajaran. Mendiskusikan langkah-langkah penerapan pembelajaran kooperatif dengan mengunakan teknik kancing gemerincing setelah di dapat refleksi dari siklus I.

b. Pelaksanaan Tindakan

Kegiatan pembelajaran pada pertemuan pertama siklus II ini adalah guru memberitahukan indikator 
pencapaian hasil belajar dan memotivasi siswa. Guru menjelaskan materi pelajaran. Untuk selanjutnya siswa diminta memperdalam materi yang terdapat dalam buku yang telah di tetapkan, dan apabila mengalami kesulitan boleh bertanya kepada teman sekelompoknya. Selesai memperdalam materi siswa diminta mengerjakan soal-soal yang ada dalam buku dengan menggunakan pembelajaran kooperatif dengan teknik kancing gemerincing. Ketika melakukan pembelajaran kooperatif dengan teknik kancing gemerincing guru mengamati dan membimbing siswa bekerja.

Pada pertemuan pertama siklus II ini pembelajaran kooperatif dengan teknik kancing gemerincing berjalan baik, dan siswa sudah mulai terbiasa. Guru memberikan kuis sekitar 10 menit. Diakhir pelajaran guru bersama siswa menyimpulkan pelajaran hari ini, siswa diberi PR dan guru membagikan kuis pada pertemuan pertama kemudian guru memberikan penghargaan kepada kelompok yang memiliki nilai tertinggi.

Kegiatan pembelajaran pada pertemuan kedua siklus II ini adalah guru memberitahukan indikator pencapaian hasil belajardan memotivasi siswa. Guru menjelaskan materi pelajaran secara garis besar dan menjelaskan satu contoh yang ada dalam buku yang telah ditetapkan. Untuk selanjutnya siswa diminta memperdalam materi yang terdapat dalam buku yang telah di tetapkan, dan apabila mengalami kesulitan boleh bertanya kepada teman sekelompoknya. Selesai memperdalam materi siswa diminta untuk mengerjakan soal-soal yang ada dalam buku dengan menggunakan pembelajaran kooperatif dengan teknik kancing gemerincing. Ketika melakukan pembelajaran kooperatif dengan teknik kancing gemerincing guru mengamati dan membimbing siswa bekerja.

Pada pertemuan kedua siklus II ini pembelajaran kooperatif dengan teknik kancing gemerincing berjalan lebih baik, dan siswa sudah mulai terbiasa. Guru memberikan kuis sekitar 10 menit, akhir pelajaran guru bersama siswa menyimpulkan pelajaran hari ini dan guru membagikan kuis pada pertemuan ketua kemudian guru memberikan penghargaan kepada kelompok yang memiliki nilai tertinggi.

\section{c. Observasi}

Observasi dilakukan terhadap pelaksanaan pembelajaran setiap pertemuan. Dari hasil analisis diperoleh penilaian pelaksanaan pembelajaran kooperatif dengan teknik kancing gemerincing sudah baik. ini terlihat dari persentase yang diperoleh yaitu 93,30\%. Dalam hal ini adanya peningkatan dari siklus I. Setiap aspek yang dinilai mulai dari pendahuluan sudah baik, kegiatan inti juga sudah baik meskipun ada 
beberapa aspek dinilai cukup baik sampai pada penutupnya.

\section{d. Refleksi}

Dari tindakan dan hasil observasi siklus II diperoleh beberapa data. Data diolah dan dianalisis sebagai berikut, refleksi pelaksanaan pembelajaran kooperatif dengan teknik kancing gemerincing dari hasil analisis diperoleh penilaian pelaksanaan pembelajaran kooperatif dengan teknik kancing gemerincing pada siklus II mengalami peningkatan dibanding pada siklus I. Ini terlihat dari persentase yang diperoleh yaitu 93,30\%. Namun demikian pengelolaan kelas masih perlu ditingkatkan. Refleksi hasil tes dari data hasil tes tahap II terlihat secara klasikal rata-rata hasil tes 81,88 . Jumlah siswa yang tuntas 21 orang, persentase siswa yang tuntas belajar 91,30\%. Hal ini menunjukan sudah tercapainya ketuntasan belajar yang ideal tetapi dapat dikatakan upaya peningkatan hasil belajar siswa dapat dilakukan dengan menggunakan pembelajaran kooperatif dengan teknik kancing gemerincing. Karena mengungat keterbatasan waktu, biaya dan tenaga maka peneliti hanya melaksanakan sampai siklus II.

\section{SIMPULAN}

Berdasarkan hasil analisis dan pembahasan pada bab IV di atas dapat disimpulkan bahwa penerapan pembelajaran kooperatif dengan teknik kancing gemerincing dapat meningkatkan hasil belajar kelas IV Sekolah Dasar Negeri 008 Langgini. Keberhasilan ini dibuktikan dengan adanya peningkatan hasil belajar sebelum dilakukan tindakan ke siklus I dan ke siklus II.

Pelaksanaan pembelajaran matematika menggunakan pembelajaran kooperatif dengan teknik kancing gemerincing secara umum telah berlangsung baik. Pelaksanaan pembelajaran matematika menggunakan pembelajaran kooperatif dengan teknik kancing gemerincing dapat meningkatkan hasil belajar siswa.

Hal ini terlihat dari rata-rata skor test 1 yaitu 74,54 dan rata-rata. Tes II yaitu 81,88. Pelaksanaan pembelajaran matematika menggunakan pembelajaran kooperatif dengan teknik kancing gemerincing dapat meningkatkan motivasi siswa. Hal ini terlihat dari persentase motivasi siswa pada siklus 1 yaitu $81,25 \%$ dansiklus II yaitu $91,30 \%$.

\section{DAFTAR RUJUKAN}

Arikunto. (2006). Penelitian Tindakan Kelas. Jakarta: Bumi Aksara.

Lie, $\quad 2002$. Cooperative Learning. Jakarta: PT Gramedia Widia Swara.

Slameto. 1995. Belajar dan FaktorFaktor yang Mempengaruhi. Jakarta: Rineka Cipta. 
Rusdial Marta: Peningkatan Hasil Belajar ..

Soedjadi, R. 2000. Kiat Pendidikan Matematika di Indonesia, Jakarta: Dirjen Diktat Depdiknas.

Sudjana. 1996. Metode Statistika, Bandung: Transito.

Wardani. (2007). Penelitian Tindakan Kelas. Jakarta: UT.

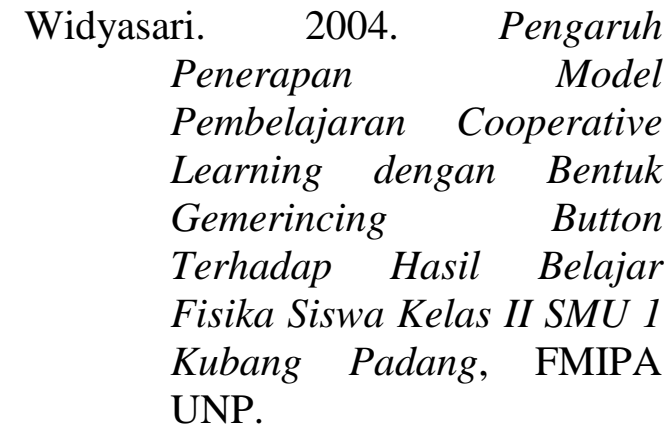

